\title{
EFFECT OF LAND USE CHANGE ON SOIL ORGANIC CARBON
}

\author{
GABRIELA BARANČÍKOVÁ*, JARMILA MAKOVNÍKOVÁ, JÁN HALAS
}

\author{
National Agriculture and Food Centre - Soil Science and Conservation
}

Research Institute, Bratislava, Slovak Republic

BARANČÍKOVÁ, G. - MAKOVNÍKOVÁ, J. - HALAS, J.: Effect of land use change on soil organic carbon. Agriculture (Pol'nohospodárstvo), vol. 62, 2016, no. 1, pp. 10-18.

\begin{abstract}
The direction of changes and conversion of soil organic carbon (SOC) is in most current ecosystems influenced by human activity. Soil Science and Conservation Research Institute is responsible for monitoring the agricultural soils in a five- year cycle. One part of the soil monitoring involves the determination of the soil organic carbon (SOC) storage. Further, we followed the conversion of arable land on grassland during more than 20 years of monitoring period at some locations where changes in land use occurred. Ten places on basic network and 2 places on key monitoring localities in which arable land have been converted into grassland were identified. About 50 percent of studied soils converted into permanent grassland were Cambisols. The other converted soil types were Luvic Stagnosol, Stagnic Regosol, Mollic Fluvisol, and Stagnic Luvisol. The results showed that after the third monitoring cycle (2002), increase of SOC was observed in all the localities, with the change in land use. Statistical parameter (t-test) confirmed significant differences between the set of average SOC values before and after the land use conversion. The chemical structure of humic acids (HA) isolated from arable soil and permanent grassland indicated increasing of aliphatic carbon content in grassland HA. More aromatic and stabile were HA isolated from arable soils.
\end{abstract}

Key words: soil organic carbon, total nitrogen, humic acids, arable land, grassland

The soil organic matter (SOM) and its key component, soil organic carbon (SOC), is one of the most important elements in the soil system. SOC is substantive and energetic basis of all biological soil processes and thus it is the basis of the most productive and nonproductive soil function. SOC is also one of the major criteria in the internationally used soil classification system (Micheli et al. 2014). The direction of changes and conversion of SOC is in the most current ecosystems influenced by human activity - land use. This is especially true for agricultural land, where soil organic matter represents more as $95 \%$ (pastures, meadows) or almost $100 \%$ (arable land) of total organic carbon accumulated in human-amended ecosystems (Stolbovoy \& Montanarella 2008). The changes in land use means changes in total stock of soil organic carbon. The soils easily and quickly lose organic carbon when natural soils are converted into agricultural soils as vice versa (changes of arable land to permanent grassland, or meadows, respectively agroforestry). It is estimated that soil cultivation, mainly conversion of pasture into arable land, leads to significant organic carbon loses in the overall balance up to 50Pg (Janzen 2006); conversely land-use change can offer an opportunity for sequestering atmospheric carbon in soils (Janzen 2006). Guo and Gifford (2002), on the basis of meta analysis, show that the conversion of pasture into arable land SOC decreased up to 59\%; however, change from crop to pasture can increase the SOC stock (19\%). Dawson and Smith (2007) also reported decrease of SOC

RNDr. Gabriela Barančíková, CSc. (*Corresponding author), Ing. Ján Halas, PhD., National Agriculture and Food Centre, Soil Science and Conservation Research Institute, regional working place Prešov, Raymannova 1,08001 Prešov, Slovak Republic. E-mail: g.barancikova@vupop.sk

RNDr. Jarmila Makovníková, CSc., National Agriculture and Food Centre, Soil Science and Conservation Research Institute, regional working place Banská Bystrica, Mládežnícka 36, 97404 Banská Bystrica, Slovak Republic 
stock by conversion of forest or meadow into arable land, however, converted cropland to grassland can be sequestrated to soil carbon. Smith (2014) notes that the accumulation of organic carbon by grasslands will only occur under optimal management. Generally, it can be concluded that wherever one of the land use decreases the soil organic carbon, the reverse process usually increases it and vice versa (Guo \& Gifford 2002). In present time, when climate changes induced a loss of SOC, land use has the great impact on SOC dynamics on the landscape scale (Minasny et al. 2014). Changes in land use occurred also in the Slovak agricultural lands and during the last 20 years, it is observed decreasing of arable lands and increasing of grasslands (Statistical Yearbook of the Slovak Republic 1994, 2014). In Slovakia, it has been the regular soil monitoring since 1993 in a five-year cycle. One part of the soil monitoring system is also monitoring of soil organic carbon stock. More than 20 years of monitoring showed the changes in SOC stock, especially after land use conversion.

In this work, we present the changes in content and quality of soil organic matter and total nitrogen on monitoring localities after conversion of arable lands into permanent grasslands.

\section{MATERIAL AND METHODS}

Monitoring network, with five-year monitoring cycle, on the selected 10 localities is given in Figure 1. Changes in SOC stock after land use conversion were detected in the following soil types: Haplic Cambisols, Stagnic Cambisols, Luvic Stagnosol, Stagnic Regosol, Mollic Fluvisol, and Stagnic Luvisol (Societas pedologica slovaca 2014). Changes of SOC stock were also found in Haplic Cambisol (HC) and Haplic Stagnosol (HS) after conversion of arable land to grassland on two key monitoring localities (Figure 1).

Soil organic carbon content was determined according to Turin method in Nikitin modification in 1993, 1997, and 2002. In 2007, the total content of $\mathrm{C}$ and $\mathrm{N}$ was determined using analyser EA (Barančíková et al. 2011). For the evaluation of SOC values, $>3 \%$ of previous cycle with last one (2007) PTF function was used. The comparison of dif- ferences in SOC stock between results of EA and Turin method is published in Barančíková and Makovníková (2015). Total nitrogen $\left(\mathrm{N}_{\text {tot }}\right)$ was determined in 1993, 1997, and 2002 according to the Jodlbauer method (Fiala et al. 1999). In 2007, we also determined $\mathrm{N}_{\text {tot }}$ on $\mathrm{C}, \mathrm{N}$ by analyser EA (Barančíková et al. 2011). Both methods of $\mathrm{N}_{\text {tot }}$ determination gave the same results. Qualitative parameter such as optical parameter $\left(\mathrm{Q}_{6}^{4}\right)$ was determined according to Konovovova-Bel'čikova method (Barančíková et al. 2011).

Isolation of humic acids (HA) was realised according to the IHSS method. The basic parameters of HA chemical structure (elemental analysis and parameters calculated of ${ }^{13} \mathrm{C}$ NMR spectra) were found (Barančíková et al. 2011).

Statistical analysis and data evaluation were carried out using the program Statgraphic XV. Centurion.

\section{RESULTS AND DISCUSSION}

\section{Land use changes on localities of basic network}

Land-use conversion can be found in all of the Slovak regions (Figure 1). It includes different soil types (Table 1), however, mostly Cambisols (50\%) were studied. Cambisols are the most widespread soil type in Slovakia (Bielek 2014). They occur mainly on hilly and mountain regions, which in last 20 years were converted from arable land into permanent grasslands (Bielek 2014; Statistical Yearbook of the Slovak Republic 1994, 2014).

All the observed localities were divided into three groups. The first group includes only Cambisols, and the second rest of the soil types (Luvic Stagnosols, Stagnic Regosol, Mollic Fluvisol, and Stagnic Luvisol), and the third group represents all the localities (Table 1). There were three monitoring cycles - the first in 1993, the second in 1997, and the third in 2002. At the beginning of soil monitoring (1993), all of soils were used as arable lands. In the second monitoring cycle (1997), some of them were converted into the grassland. In 2002 (the third monitoring cycle), all of them were used as permanent grassland (Table 1). Moreover, in 2013 (the fourth monitoring cycle), two of them were completely removed from agricultural land resources. 
This confirms the trend of agricultural land decreasing in Slovakia in the last five years (Statistical Yearbook of the Slovak Republic 1994, 2014).

In Figure 2, the average values for three soil groups in three monitoring cycles are given. The results show that conversion of arable land into grassland leads to increasing of SOC. This trend is similar on Cambisols (group 1), on group 2, where different soil types are present, and on all the observed localities (group 3). The increase of SOC from crop to pasture is in agreement with literature data (Guo \& Gifford 2002).
In determining the differences of SOC between arable land and grassland, we compared the two sets. File arable land (SOC average values of individual locations during their use as arable land) and a set of grasslands (SOC average of the same locations during their use as grasslands). Figure 3 (Box-Whisker plot) shows the significant difference in average between the arable lands and permanent grasslands (test to compare means $t$-test, $t=-2.10014$, the level of significance $\alpha=0.05$ ).

It is clear that higher SOC values are in grassland to compare with cropland (Gerzebek et al. 2006;

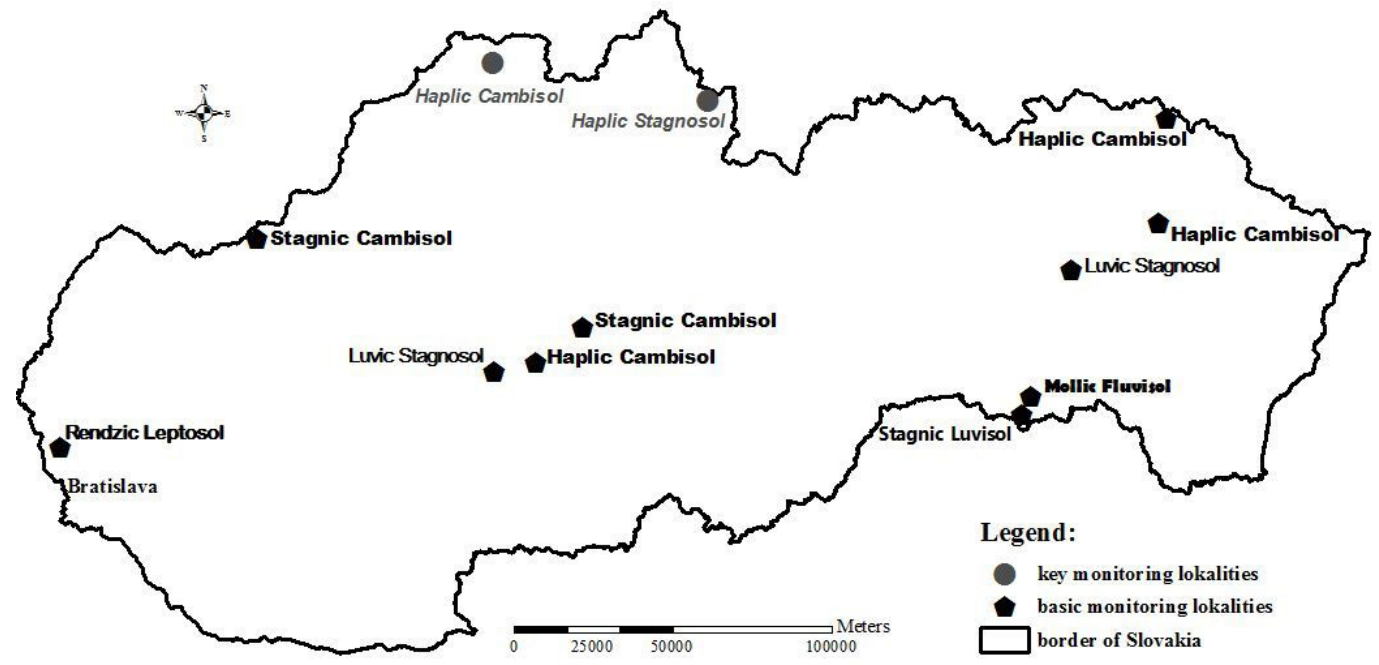

Figure 1. Localities of basic network and key monitoring localities with land-use change

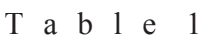

Monitoring localities of basic network with land use change

\begin{tabular}{|c|c|c|c|c|c|c|c|}
\hline \multirow{2}{*}{ Group } & Locality & Soil type & \multicolumn{4}{|c|}{ Land use } \\
\cline { 3 - 7 } & Horná Mičiná & Stagnic Cambisol & AL & G & G & G & G \\
& Tŕnie & Haplic Cambisol & AL & AL & G & G & G \\
& Nová Bošáca & Stagnic Cambisol & AL & AL & G & G & G \\
& Krajná Bystrá & Haplic Cambisol & AL & G & G & G & G \\
& Turany & Haplic Cambisol & AL & G & G & G & G \\
& Záborské & Luvic Stagnosol & AL & AL & G & G & G \\
& Horné Opatovce & Luvic Stagnosol & AL & G & G & G & 0 \\
& Vel'ká Ida & Mollic Fluvisol & AL & G & G & G & G \\
& Záhorská Bystrica & Stagnic Regosol & AL & AL & G & G & 0 \\
& Nižný Lánec & Stagnic Luvisol & AL & G & G & G & G \\
\hline
\end{tabular}

$\mathrm{AL}$ - arable land; $\mathrm{G}$ - grassland; 0 - nonagricultural land 
Barančíková 2014; Gelaw et al. 2014; Manu et al. 2014; Sanford 2014). Generally speaking, higher input of plant and root residues in grassland soils is stabilizing the SOC stock in the top soil. The wrong soil management, mainly intensive agriculture and low input of organic debris, can highly increase the mineralization processes. The last caused decreasing of SOC in the arable land.
Soil organic matter is an important source of basic biogenic elements for plant growth. More than $95 \%$ of the most important biogenic elements such as nitrogen and sulfur are bound in SOM (Baldoc \& Nelson 1999). In accordance with this statement, the values of total nitrogen are in close relationship with soil organic carbon content. Our results confirmed this fact and the significant linear correlation $\left(R=0.85^{++}\right.$,

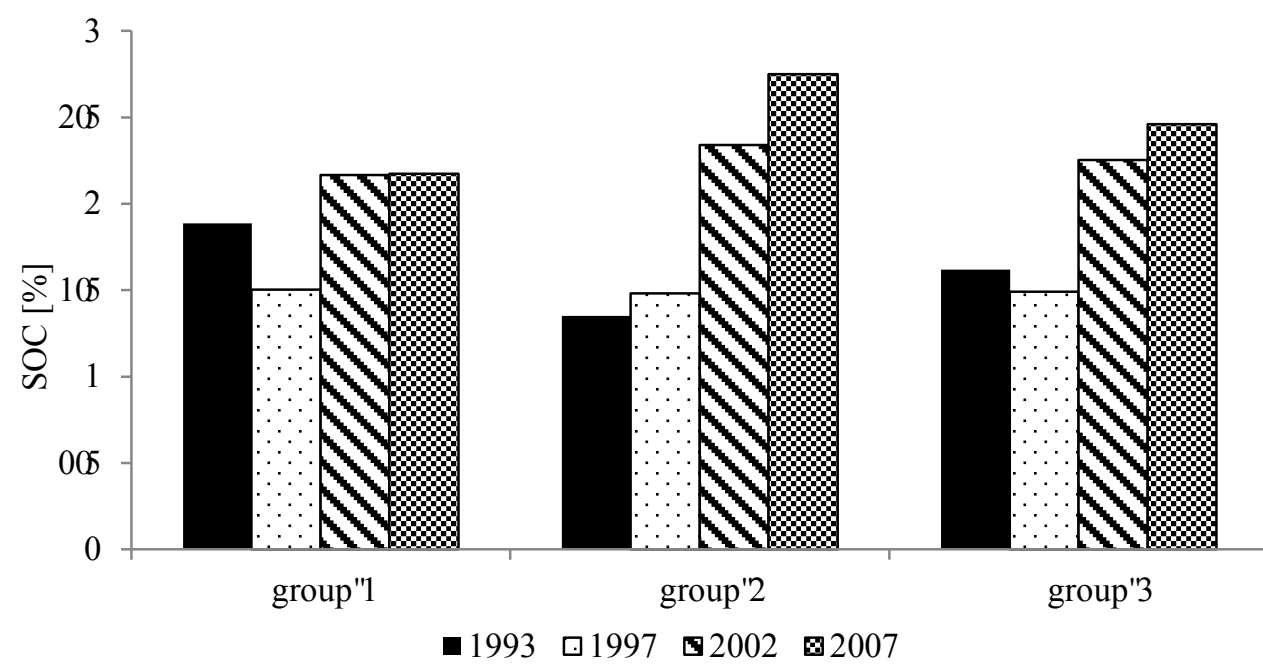

group 1 - Cambisols; group 2 - Luvic Stagnosol; Stagnic Regosol; Mollic Gleyic Fluvisol, and Stagnic Cutanic Luvisol; group 3 - all soil types

SOC - soil organic carbon

Figure 2. Average values of SOC on localities where the land use change was found

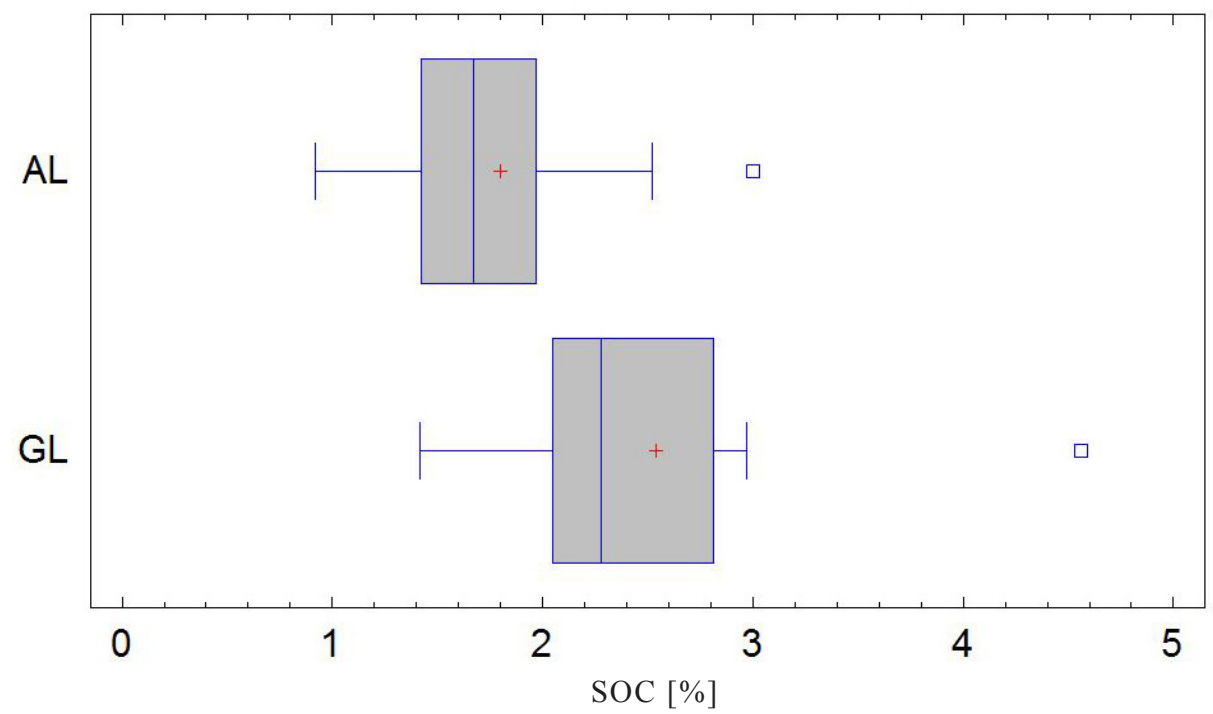

AL - average value of SOC for arable land; GL - average value of SOC for grassland; SOC - soil organic carbon

Figure 3. Box-Whisker plot 
$\mathrm{n}=10$ ) between $\mathrm{N}_{\text {tot }}$ and SOC was found. Increasing of total $\mathrm{N}_{\text {tot }}$ after conversion of arable land was observed (Figure 4).

\section{Land use changes on key monitoring localities}

Changes of SOC stock were also found in Haplic Cambisol (HC) and Haplic Stagnosol (HS) after conversion of arable land to grassland in two key monitoring localities. These soil types represent the less productive agricultural soils (Bielek 2014). Both of these localities were situated in the north part of Slovakia (Figure 1) in the mountain region. Soil sampling was done here every year. At the beginning of soil monitoring (time period 1994-2001), these localities were used as arable land and later they became permanent grasslands. The comparison

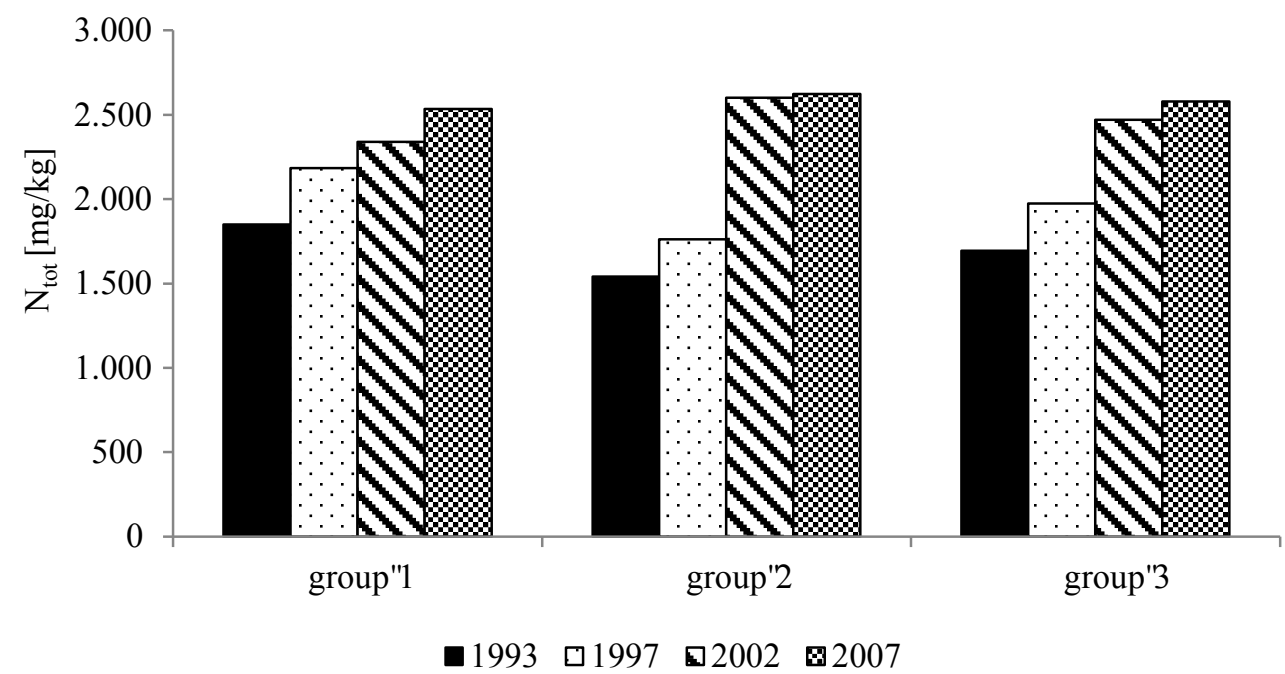

group 1 - Cambisols; group 2 - Luvic Stagnosol; Stagnic Regosol; Mollic Gleyic Fluvisol and Stagnic Cutanic Luvisol; group 3 - all soil types

$\mathrm{N}_{\text {tot }}$ - total nitrogen

Figure 4. Average values of $\mathrm{N}_{\text {tot }}$ on localities where the land use change was found

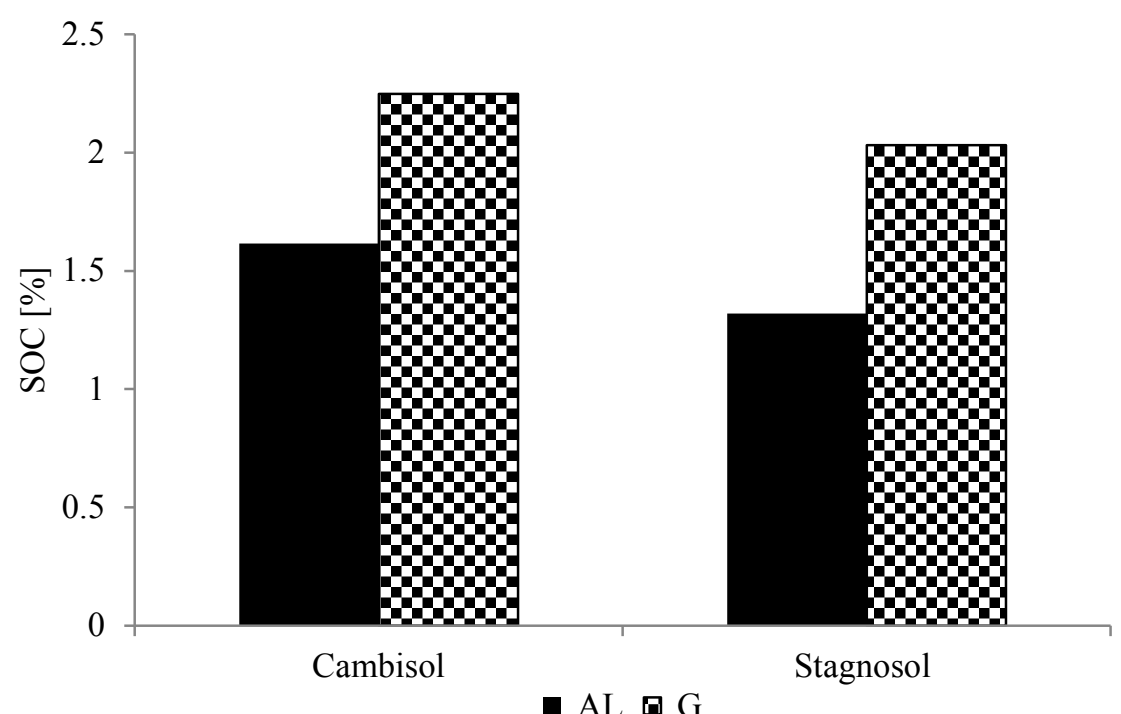

AL - average value of SOC of time period 1994-2001 (arable land); G - average value of SOC of time period 2002-2014 (grassland); SOC - soil organic carbon

Figure 5. Development of SOC on two key monitoring localities during monitoring period 
of average SOC values during 1994-2001, when these localities were used as arable land (AL), and during 2002-2014, when these localities were converted into the grassland (G), are given in Figure 5.

Total nitrogen content is given in Figure 6. Increase of SOC content and $\mathrm{N}_{\text {tot }}$ content after land conversion was evident.
Qualitative parameters, such as absorption in UV-VIS spectral range and $\mathrm{Q}_{6}^{4}$ indexes, were determined. The optical index $\left(\mathrm{Q}_{6}^{4}\right)$ represents the absorbance ratio of humic acid solution at $\lambda=465$ and $\lambda=665 \mathrm{~nm}$ (Barančíková et al. 2011). Higher values of this parameter are characteristic of more labile and less mature soil organic matter, and on the con-

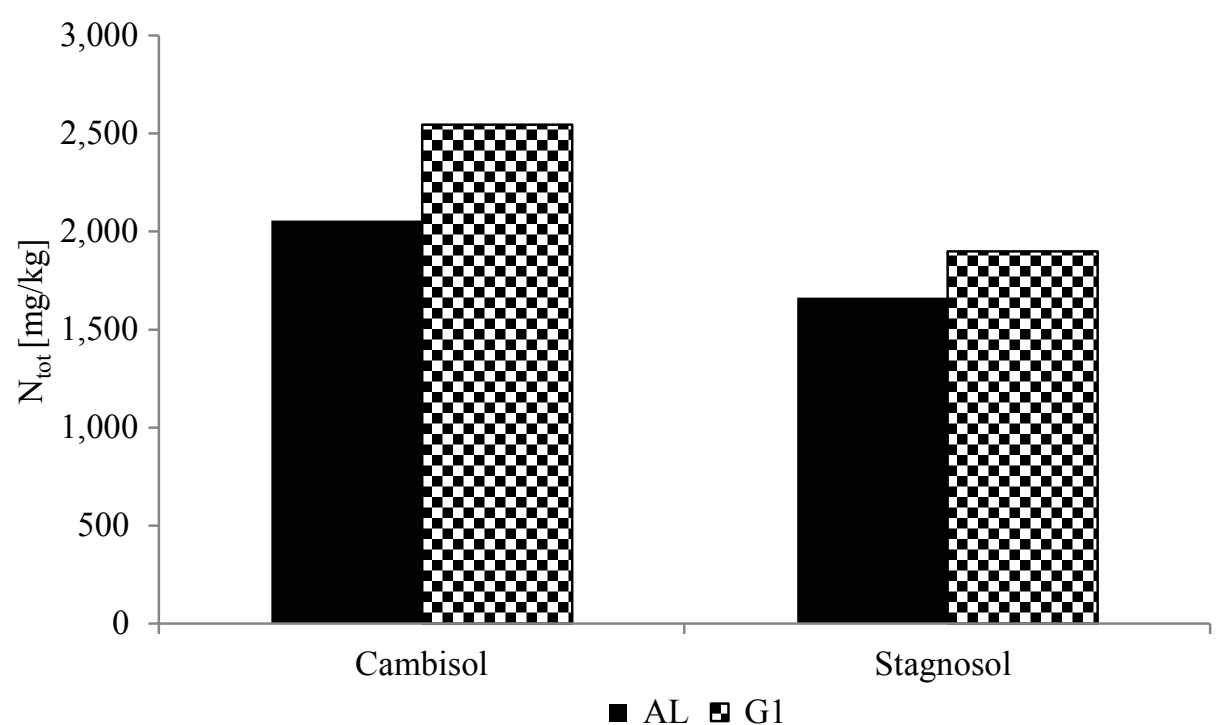

AL - average value of $\mathrm{N}_{\text {tot }}$ of time period 1994-2001 (arable land); G - average value of $\mathrm{N}_{\text {tot }}$ of time period 2002-2014 (grassland)

Figure 6. Development of $\mathrm{N}_{\text {tot }}$ on two key monitoring localities during monitoring period

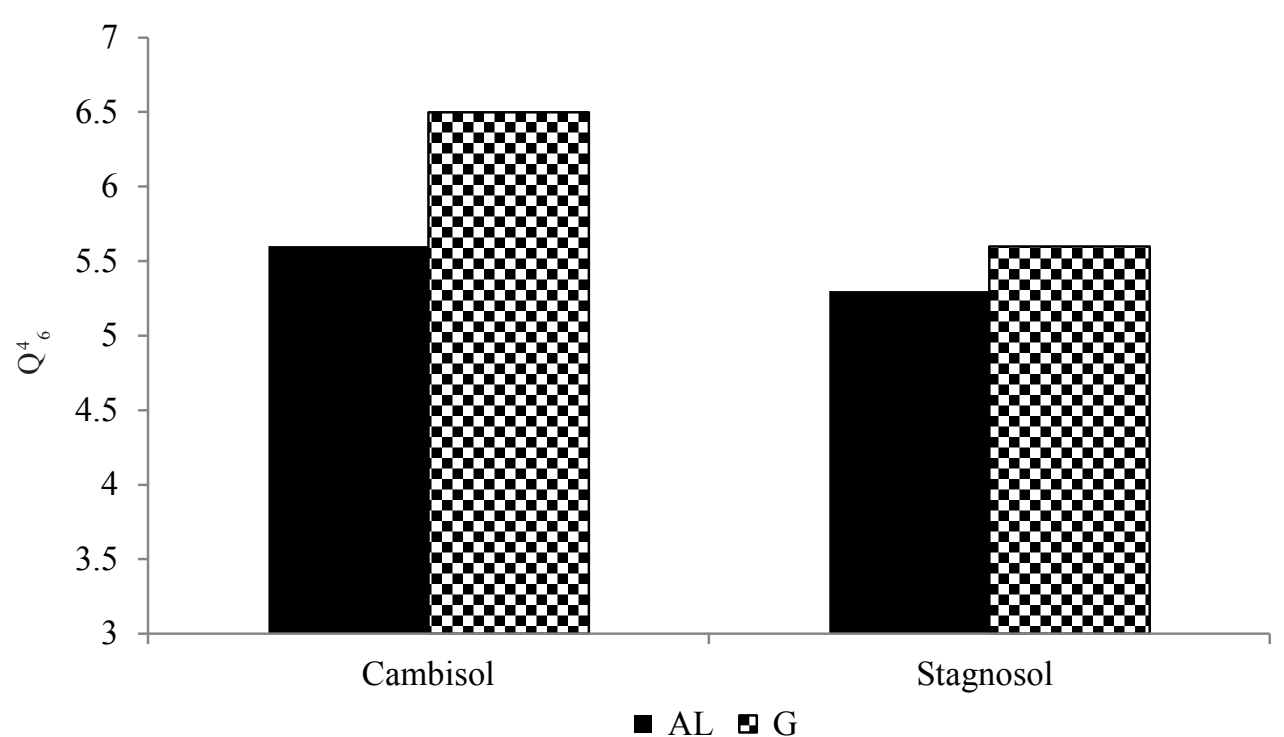

$\mathrm{AL}$ - average value of $\mathrm{Q}_{6}^{4}$ of time period 1994-2001 (arable land); $\mathrm{G}$ - average value of $\mathrm{Q}_{6}^{4}$ of time period 2002-2014 (grassland)

Figure 7. Development of $\mathrm{Q}_{6}^{4}$ on two key monitoring localities during monitoring period 
trary lower values of $\mathrm{Q}_{6}^{4}$ are typical of mature and well-humificated soil organic matter. Both observed localities showed higher values of $\mathrm{Q}_{6}^{4}$ in grassland soils to compare with arable soil. We can assume that more labile and less mature is SOM of grassland compared with arable soils (Figure 7).

Humic acids were isolated every three years from the key monitoring localities. HA from $\mathrm{HC}$ were isolated in 1995, 1998, 2001, 2004, 2007, and 2012. HA from HS were isolated in 1994, 1997, 2000, 2003, 2006, 2009, 2014. Data gathered during 1995-2001 represent HC used as arable soil. Data collected during 2004-2012 represent the same soil used as permanent grassland. Data obtained during 1994-2000 represent HS used as arable soil. Data that were collected during 2003-2014 represent the same soil used as permanent grassland.

Evaluation of HA structure and elemental composition reflect the dominant characteristic of soil humification. Depending on the HA origin, the carbon content differs. Generally, it represents $35-50 \%$ atomic carbon, and $35-45 \%$ atomic hydrogen (Than 2003). Higher content of carbon and lower percentage of hydrogen is characteristic for organic materials with a higher humification degree. The results obtained for HA elemental composition in Haplic

T a b $\quad$ b e 2

Elemental composition and calculated parameter of ${ }^{13} \mathrm{C}$ NMR spectra of humic acids

\begin{tabular}{|l|c|c|c|c|c|c|c|}
\hline $\mathrm{HA}$ & $\mathrm{C}$ & $\mathrm{H}$ & $\mathrm{O}$ & $\mathrm{N}$ & $\mathrm{C}_{\mathrm{alif}}[\%]$ & $\mathrm{C}_{\mathrm{ar}}[\%]$ & $\alpha[\%]$ \\
\hline X-AL HS & 41.00 & 40.17 & 15.82 & 3.00 & 46.85 & 33.81 & 41.94 \\
X-G HS & 40.62 & 39.54 & 16.25 & 3.60 & 49.51 & 33.45 \\
X-AL HC & 38.94 & 41.04 & 16.29 & 3.75 & 50.54 & 29.42 \\
X-G HC & 38.53 & 40.25 & 17.12 & 4.10 & 56.85 & 25.01 \\
\hline
\end{tabular}

$\mathrm{x}-\mathrm{AL}$ average value of elemental analyses and calculated parameters of ${ }^{13} \mathrm{C}$ NMR spectra for arable land $\mathrm{x}-\mathrm{G}$ average value of elemental analysis and calculated parameters of ${ }^{13} \mathrm{C} N \mathrm{NMR}$ for grassland

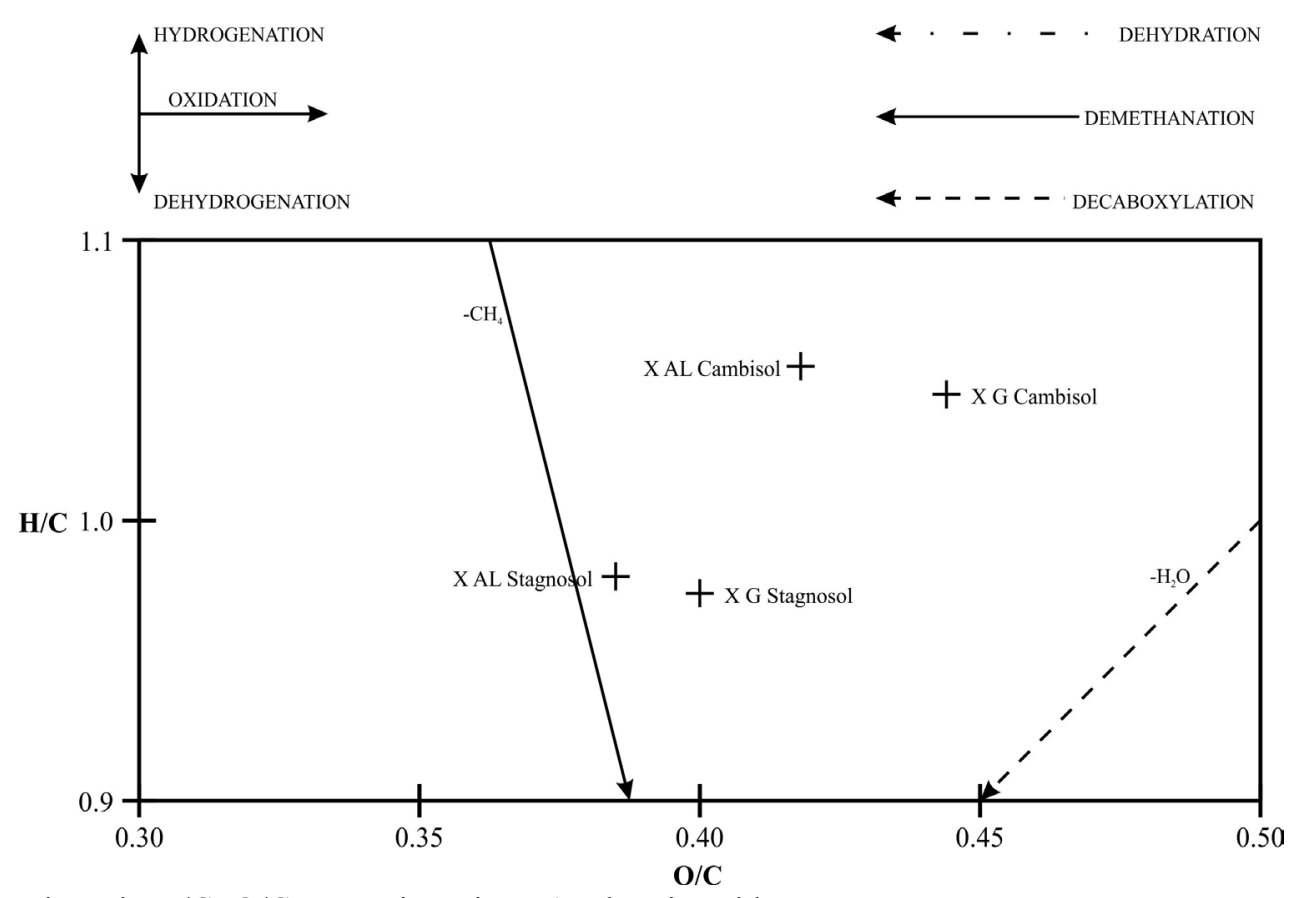

$\mathrm{H} / \mathrm{C}$-atomic ratio $\mathrm{H} / \mathrm{C}$; $\mathrm{O} / \mathrm{C}$ - atomic ratio; $\mathrm{HA}$ - humic acids

Figure $8 . \mathrm{H} / \mathrm{C}$ versus $\mathrm{O} / \mathrm{C}$ diagram for $\mathrm{HA}$ 
Cambisol and Haplic Stagnosol are typical of these soil types and are in accordance with the published literature (Barančíková 2014). As evident from Table 2, decreasing of carbon and hydrogen in HA molecule after land conversion was determined. On the other hand, increase of oxygen and nitrogen in HA molecule was observed (Table 2).

Atomic ratios calculated from $\mathrm{HA}$ elemental composition is presented in the form of Van Krevelen diagram (Figure 8). The ratios $\mathrm{H} / \mathrm{C}$ and $\mathrm{O} / \mathrm{C}$ were used for graphic-statistical analyses. This is useful for evaluating the chemical processes influencing the HA formation. Van Krevelen diagram (Figure 8) indicated oxidation trend in grassland HA.

The results of ${ }^{13} \mathrm{C}$ NMR spectroscopy are very useful for HA structure (Novák \& Hrabal 2011; Enev et al. 2014). ${ }^{13} \mathrm{C}$ NMR spectroscopy can quantitatively detect different carbon types (e. g. carbonyl, carboxyl, aromatic, olephinic, anomer, aliphatic carbon) in HA molecule. The most important ${ }^{13} \mathrm{C}$ NMR parameters are percentage of aliphatic $\left(\mathrm{C}_{\text {alif }}\right)$ and aromatic $\left(\mathrm{C}_{\mathrm{ar}}\right)$ carbon, and aromaticity degree $(\alpha)$. Calculation of aromaticity degree was done according to Hatcher (1981). The predominance of aliphatic structure and relatively low aromaticity degree (Table 2) was characteristic for HA isolated from $\mathrm{HC}$ and HS. After land conversion, increasing of $\mathrm{C}_{\text {alif }}$ and decreasing of $\mathrm{Car}_{\text {ar }}$ take place in permanent grasslands (Table 2). These findings are consistent with the results of Perez et al.( 2004), who reported that such trend is characteristic of a higher incorporation of plant residues in SOM. Ono et al. (2009) also found out that after incorporation of fresh organic matter content of aliphatic carbon increased and the aromaticity degree decreased. Gonzales-Perez et al. (2007) reported that HA isolated from uncultivated land contained less percentage of aromatic carbon in comparison with arable land.

\section{CONCLUSIONS}

Our results confirm that land use change is a main factor influencing content and quality of soil organic carbon. Soil monitoring system is a valuable tool for the observation of these changes. On the basis of statistical analysis, it can be concluded that after land conversion grasslands dispose by higher content of soil organic carbon in comparison to arable land. Higher input of plant and root residues in grassland soils is stabilizing SOC stock in the top soil. Also higher content of total nitrogen in grassland opposite to cropland was found. After conversion of land use, the changes also occurred in quality of soil organic matter. The obtained results show more labile and less mature SOM of grassland to compare with arable soils. Higher input of plant residues and incorporation of fresh organic matter on grassland reflected in changes of humic acid chemical structure. The changes in HA chemical structure confirm the increase in aliphatic carbon content and decrease in aromaticity degree

Acknowledgments. This work was supported by the Slovak Research and Development Agency under the contract No. APVV-0243-11, No. APVV14-0087, and No. APVV-0098-12.

\section{REFERENCES}

BALDOCK, J.A. - NELSON, P.N. 1999. Soil Organic matter. In SUMMER, M.E. (Ed) Handbook of Soil Science. Boca Raton : CRC Press. pp. B25-B84. ISBN 0-8493-3136-6

BARANČÍKOVÁ, G. - BEZÁK, P. - DODOK, R. CHLPÍK, J. - KOBZA, J. - MAKOVNÍKOVÁ, J. PÍŠ, V. 2011. Methods of determining indicators of agrochemical soil properties. In HRIVŇÁKOVÁ, K. MAKOVNÍKOVÁ, J. (Eds) Integrated procedures of soil analyse. Bratislava : VUPOP. pp. 52-115. ISBN 978-80-89128-89-1

BARANČÍKOVÁ, G. 2014. Monitoring of quantitative and qualitative composition of soil organic mater. In KOBZA, J. (Ed) Soil monitoring of the Slovak republic. Actual state and development og monitoring soil properties as the basis for their protection and land use (the period 2007-2012). Bratislava : NPPC -VUPOP. pp. 53-89. ISBN 978-80-8163-004-0

BARANČÍKOVÁ, G. - MAKOVNÍKOVÁ, J. 2015. Comparison of two methods of soil organic carbon determination. In Polish Journal of Soil Science, vol. XLVIII/I, pp. 47-56. DOI: 10.1795/pjss/2015.48.1.47

BIELEK, P. 2014. Compendium of practically oriented soil science. Nitra : Slovenská Pol'nohospodárska univerzita. pp. 135-143. ISBN-978-80-552-1155-8

DASON, J.J.C. - SMITH, P. 2007. Carbon losses from soil and its consequences for land-use management. In Review Science of the Total Environment, vol. 382, pp. 165-190. DOI: 10.1016/j.scitotenv.2007.03.023

DOANE, T.A. - DEVEVRE, O.C. - HORWATH, W.R. 2003. Short-term soil carbon dynamics of humic fractions in low-input and organic cropping systems. In 
Geoderma, vol. 114, no. 3, pp. 319-331. DOI:http:// dx.doi.org/10.1016/S0016-7061(03)00047-8

ENEV, V. - POSPÍŠILOVÁ, L. - KLUČÁKOVÁ, M. LIPTAJ, T. - DOSKOČIL, L. 2014. Spectral characterization of selected humic substances. In Soil and Water Research, vol. 9, no. 1, pp. 9-17.

FIALA, K. 1999. Partial monitoring system - soil: obligatory methods. Bratislava: VUPOP. pp. 54-57. ISBN 80-85361-55-8

GELAW, M.A. - SINGH, B.R. - LAL, R. 2014. Soil organic matter and total nitrogen stocks under different land uses in semi-arid watershed in Tigray. Northern Ethiopia. In Agriculture, Ecosystems and Environment, vol. 118, pp. 256-263. DOI: http://dx.doi. org/10.1016/j.agle.2014.02.035

GERZEBEK, M.H. - ANTIL, R.S. - KOGEL-KNABNER, I. - KNICKER, H. - KIRSCHMANN, H. - HABERHAUER, G. 2006. How are soil use and management reflected by soil organic matter characteristics: a spectroscopic approach. In European Journal of Soil Science, vol. 57, no. 4, pp. 485-494. DOI:10.1111/ j.1365-2389.2006.0079.x

GONZALES-PEREZ, M. - MILORI, D.M.B.P. - COLNAGO, L.A. - MARTIN-NETO, L. - MELO, W.J. 2007. A laser-induced fluorescence spectroscopic study of organic matter in a Brazilian Oxisols under different tillage systems. In Geoderma, vol. 138, no. 1-2, pp. 20-24. DOI:10.1016/j.geoderma.2006.10.010

GUO, L.B. - GIFFORD, R.M. 2002. Soil carbon stocks and land use change: a meta analysis. In Global Change Biology, vol. 8, no. 4, pp. 345-360. DOI: 10.1046/j.1354-1013.2002.00486.x

HATCHER, P.G. - SCHNITZER, M. - DENNIS, L.M. - MACIEL. G.E. 1981. Aromaticity of humic substances in soils. In Soil Science Society of America Journal, vol. 45, no. 6, pp. 1089-1094. DOI:10.2136/ sssaj 1981.03615995004500060016x

JANZEN, H.H. 2006. The soil carbon dilemma: shall we hoard it or use it. In Soil Biology and Biochemistry, vol. 38, no. 3, pp. 419-424. DOI:10.1016/j.soilbio. 2005.10 .008

MANU, V. - WHITBREAD, A. - BLAIR, N. - BLAIR, G. 2014. Carbon status and structural stability of soils from different land use systems in the Kingdom of Tonga. In Soil Use and Management, vol. 30, no. 4, pp. 517-523. DOI:10.1111/sum.12135

MICHELI, E. - OWENS, P.R. - LANG, V. - FUCHSHEMPEL, J. 2014. Organic carbon as a major differentiation criterion in soil classification systems. In HARTEMINK, A. - MCSWEENEY, K. (Eds) Soil Carbon. Heildelberg : Springer Cham. pp. 37-43. ISBN 978-3-319-04083-7
MINASNY, B. - MCBRANDAN, A.B. - MALONE, B.P. - LACOSTE, M. - WALTER, C. 2014. Quantitatively predicting soil carbon across landscapes. In HARTEMINK, A. - MCSWEENEY, K. (Eds) Soil Carbon. Heildelberg: Springer Cham. pp. 45-57. ISBN 9783-319-04083-7

NOVÁK, F. - HRABAL, R. 2011. Quantitative ${ }^{13} \mathrm{C}$ NMR spectroscopy of humic acids. In Chemické listy, vol. 105, pp.752-760.

ONO, K. - HIRAI, K. - MORITA, S. - OHSE, K. - HIRADATE, S. 2009. Organic carbon accumulation processes on a forest floor during an early humification stage in a temperate deciduous forest in Japan: Evaluation of chemical composition changes by ${ }^{13} \mathrm{C}$ NMR and their decomposition rates from litterbag experiment. In Geoderma, vol. 151, no. 3-4, pp. 351-356. DOI:10.1016j.geoderma.2009.05.001

PEREZ, G.M. - MARTIN-NETO, L. - SAAB, S.C. - NOVOTNY, E.H. - MILORI, D.M.B.P. - BAGNATO, V.S. - COLNAGO, L.A. - MELO, W.J. - KNICKER, H. 2004. Characterization -of humic acids from a Brazilian Oxisol under different tillage systems by EPR. ${ }^{13} \mathrm{C}$ NMR. FTIR and fluorescence spectroscopy. In Geoderma, vol. 118, no. 3-4, pp. 181-190. DOI:10.1016/S0016-7061(03)00192-7

SANFRORD, G.R. 2014. Perennial grasslands are essential for long term SOC storage in the Mollisols of the North Central USA. In HARTEMINK, A. - MCSWEENEY, K. (Eds) Soil Carbon. Heildelberg : Springer Cham. pp. 281-288. ISBN 978-3-319-04083-7

SMITH, P. 2014. Do grasslands act as a perpetual sink for carbon? In Global Change Biology. vol. 20, no. 9, pp. 2708-2011. DOI:10.1111/gcb.12561

SOCIETAS PEDOLOGICA SLOVACA. 2014. Morphogenetic Soil Classification System of Slovakia. Bratislava : NPPC-VUPOP, 96 p. ISBN 978-80-8163-005-7

Statistical Yearbook of the Slovak Republic (1994). Veda. Bratislava. 734p.

Statistical Yearbook of the Slovak Republic (2014). Veda. Bratislava, 669p.

STOLBOVOY, V. - MONTANARELLA, L. 2008. Application of soil organic carbon status indicators for the policy-decision making in the EU. In TOTH, G. - MONTANARELlA, L. - RUSCO. J. (Eds) Threats to soil quality in Europe. Luxembourg: Office for Official Publications of the European Communities, pp. 87-99. ISBN 978-92-79-09529-0. DOI:10.2788/8647

THAN, H.K. 2003. Humic matter in soil and in the environment. New York: Marcel Dekker. pp. 127-135. ISBN 0-8247-4272-9

Received: December 15, 2015 